\section{Anne Bitsch}

Ph.d.-stipendiat i samfunnsgeografi,

Senter for tverrfaglig kjønnsforskning, Universitetet i Oslo

Foto Universitetet i Oslo

\title{
Svekket vern for overgrepsutsatte?
}

\author{
Overgrepsmottakene er sentrale \\ for å styrke de voldtektsutsattes \\ rettssikkerhet. Det er en dårlig \\ idé å flytte dem til spesialisthelse- \\ tjenesten, slik regjeringen foreslår \\ i en ny stortingsmelding.
}

«Sofia» og «Johanna» er to unge kvinner som begge ble utsatt for overgrep etter en kveld på byen. I «Sofia»s sak ble overgriperen dømt for forholdet, ikke i «Johanna»s. En vesentlig forskjell på de to sakene er at «Johanna» ikke fikk legehjelp etter overgrepet og at det ikke ble foretatt sporsikring på overgrepsmottak pga. underbemanning og lang reisevei til nærmeste mottak, mens «Sofia» fikk slik oppfølging.

Etableringen av overgrepsmottak har vært essensielt for rettssikkerheten til ofre for voldtekt og overgrep. I sin doktoravhandling undersøkte overlege Helle Nesvold ved overgrepsmottaket på Oslo legevakt helsetilbudet for ofre for seksuelle overgrep. Konklusjonen i avhandlingen er klar: Mulighetene for å få dømt voldtektsforbrytere i retten er bedre i saker hvor det innhentes rettsmedisinsk dokumentasjon, og politiet gjør også flere andre etterforskningsskritt i disse sakene. I $23 \%$ av sakene med rettsmedisinsk dokumentasjon endte det med fellende dom i retten. I saker uten slik dokumentasjon endte bare $6 \%$ med fellende dom.

Dessverre foreslår regjeringen i sin seneste stortingsmelding om vold i nære relasjoner å overføre ansvaret for over- grepsmottakene til spesialisthelsetjenesten og reservere dem for personer utsatt for seksuelle overgrep. Forslaget ble godkjent av Justiskomiteen i mai 2013.

Geografi har betydning for hvordan volds- og voldtektsofre følges opp. Ifølge en dansk studie oppsøker ofre for vold i nære relasjoner oftere hjelp når de bor i nærheten av det stedet en krisetelefon driftes fra. I et notat som i vår ble sendt til Justiskomiteen uttrykker Henriette Myhre Waitz og Helle Nesvold ved Overgrepsmottaket på Oslo legevakt bekymring for hvorvidt terskelen for å oppsøke hjelp økes hvis undersøkelse skal skje på sykehus eller hvis antall overgrepsmottak reduseres. Lang reisevei kan være et betydelig hinder for å få legehjelp og undersøkelse etter overgrep. Det samme kan avstanden til nærmeste lensmannskontor eller politistasjon være. Som «Johanna»s sak er et eksempel på, er et tilstrekkelig bemannet akuttilbud uten lang reisevei essensielt for å ivareta ofrenes rettssikkerhet. Eksisterer ikke dette, kan resultatet bli frifinnelser i retten.

Regjeringens argument for å flytte mottakene er blant annet at undersøkelse og behandling av voksne overgrepsutsatte er komplisert og at spesialistkompetanse derfor er påkrevd. De som er utsatt for relasjonsvold, skal behandles i primærhelsetjenesten, det vil si hos legevakter og fastleger, fremfor i organiserte overgrepsmottak. Fagpersoner hevder at det vil føre til splittelse av overgrepsarbeidet og til at de fleste av dagens mottak vil bli avviklet. Det vil bli vanskelig å gi et fullverdig tilbud til relasjonsvoldsutsatte, ikke minst dem som trenger akutt hjelp. Siden relasjons- vold ofte omfatter seksuelle overgrep, er det en dårlig idé å splitte det akutte overgrepsarbeidet.

Det er bra at regjeringen med stortingsmeldingen viderefører et mangeårig politisk engasjement for å hjelpe ofre for vold i nære relasjoner og voldtekt, men det er en dårlig idé å opprette en helt ny organisasjon der sykehusene må begynne fra scratch med å tilegne seg kompetanse og avsette ressurser i en hverdag som er travel nok som den er.

Lavterskeltilbudene må bestå og opprustes, slik at unge utsatte ikke blir kasteballer i systemet. Regjeringen og Stortinget må anerkjenne kompetansen til dem som i årevis har dedikert sin yrkesinnsats til å hjelpe utsatte. Selv om kompetansen og ressursene ifølge en nylig evaluering er geografisk ujevnt fordelt, er ikke dette i seg selv noe godt argument for nedleggelse. Det kan fort bli dyrt å opprette nye tilbud fra grunnen rundt omkring på landets sykehus.

Vold i nære relasjoner og voldtekt er et av vår tids store folkehelseproblemer. Skal man lykkes med å tilby de utsatte den akutthjelpen og langsiktige oppfølgingen de trenger for å komme seg videre i livet etter overgrep, må eksisterende mottak styrkes og videreutvikles, ikke legges ned. Det er både god helsepolitikk og god justispolitikk.

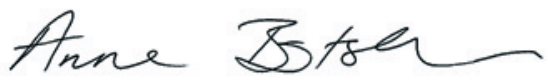

